\title{
Seeding year alfalfa population development as influenced by weed competition and density of establishment
}

\author{
SePpo Pulli \\ University of Helsinki, Dept. of Plant Husbandry, 00710 Helsinki 71
}

\begin{abstract}
The research in intraspecific competition within an alfalfa stand and interspecific competition between alfalfa and weeds was begun on the Michigan State University farm in East Lansing in 1972. Alfalfa seeding densities of 50, 400 and 800 seeds $/ \mathrm{m}^{2}$ were used to determine intraspecific competition. Interspecific competition between alfalfa and weeds occurred mainly in noncontrolled alfalfa stands at various levels of seeding densities.

Plant competition was evaluated with importance values and with relative crowding coefficients. Both measurements were found to be suitable for this kind of study.

Importance values primarily indicated the quantity relationships of different species. Relative crowding coefficients mainly characterized the competitive ability of a species in a mixed stand.

The importance of alfalfa exceeded the importance of weeds in noncontrolled and herbicide controlled stands at the seeding rates of 14 and $7 \mathrm{~kg} / \mathrm{ha}$ respectively.

Relative crowding coefficients show the competitive ability of alfalfa with regard to weeds. In the case of intraspecific competition there was no change in the crowding coefficient of alfalfa in respect of weeds when the seeding rate of alfalfa was increased beyond $9 \mathrm{~kg} / \mathrm{ha}$. The crowding coefficient of weeds presented equal values under all treatments thereby indicating the variability and plasticity of weeds. The maximum yield level was obtained in all treatments with the alfalfa seeding rate of $9 \mathrm{~kg} / \mathrm{ha}$.

The total biomass production per unit area was equal in the noncontrolled system at all seeding densities and in the herbicide controlled system at seeding rates of $9 \mathrm{~kg} / \mathrm{ha}$ or more.
\end{abstract}

\section{Introduction}

Plants compete for light, moisture and nutrients. Competition occurs between different species and among pure stands. Competition has been studied by way of mathematical models, laboratory and field experiments with single populations or limited mixtures and with influences from natural and seminatural populations growing in mixed communities with or without experimental manipulation. Mc INTOSH (1965) noted that each species has a genetic potential of response to the environment which determines if and how well it can grow on a given site. Its success is not solely dependent on site conditions, however, but is to a large degree controlled by interaction with 
other plants. The familiar measures of the competitive effect are reduction in size or reduction in reproductive capacity (plasticity) and reduction in number of plants (mortality). CooK (1965) has stated that intraspecific competition is mainly characterized by plastic response, while interspecific competition mainly results in mortality.

SAGAR and HARPER (1960), based on their experiments and observations, suggest that cohabitation of mixed populations may, in some cases, be maintained by each species suffering more from intraspecific competition than from interspecific competition.

An important point concerning the plant community is the effect of the mixture of species on the utilization of site resources. The conventional idea held by ecologists is that diversified utilization of the site resources should result in greater productivity and efficiency. Donald (1963) has noted, however, that the yield of a mixture of herbaceous plants is usually less than that of a pure stand of the higher yielding component.

Perennial forage crops represent the category in which the economic yield is the biological yield, consequently the yield response to an increasing plant population is asymptotic. In this case, reports Holliday (1960), it is important to get a stand dense enough to obtain maximum yields, but if the stand is too dense, the only loss is from greater seeding expence. From the ecological standpoint the main aim of this field study is to examine the interspecific competition of an alfalfa stand. From the agricultural standpoint the main idea is to find the optimum seeding rate and the proper management technique. In the case of a low seeding rate, weed competition can be harmful, and if the stand is too dense, the seeding expences are unnecessarily high. With clear seeding and harvesting in the year of seeding, stand density plays an important role in obtaining the maximum biological and economical yields.

\section{Materials and methods}

\subsection{Establishment}

The experiment was established on the Michigan State University farm in East Lansing in 1972. The soil was a productive, well drained Hillsdale loam soil with $\mathrm{pH}$ 6.8. Saranac, a Flemish type, vigorous, early developing variety was selected. The seed was well prepared prior to seeding. Commercial fertilizer totalling, NPK $300 \mathrm{~kg} / \mathrm{ha}(0-14-42)$ was broadcast and incorporated in the soil by discing. Germination was $93 \%$ for the alfalfa. Seeding rates were adjusted to $100 \%$ germination according to the actual germination percentage and seed weight. Saranac alfalfa was clear-seeded May 1, 1972. Establishment was done by using a Nursery planter. The plot size was $0.7 \times 7.8 \mathrm{~m}$ consisting of 5 rows, $15 \mathrm{~cm}$ apart. A compeletely randomized split-plot design was used.

Variables:

$\begin{array}{lll}\text { Variety } & \text { (main plot) } & : \text { Saranac } \\ \text { Weed control } & \text { (sub) } & : \text { treated + untreated } \\ \text { Density } & \text { (sub-sub) } & : 50,400,800 \text { seeds } / \mathrm{m}^{2} \\ \text { Replicates } & & : 2\end{array}$


Herbicide applications were $750 \mathrm{~g} / \mathrm{ha} 2,4-\mathrm{DB}$ and $1.0 \mathrm{~kg} / \mathrm{ha}$ of dalapon. Weed control treatment was timed when plants were in the 2-1eaf stage. Seeding rates were $1 \mathrm{~kg} / \mathrm{ha}, 9 \mathrm{~kg} / \mathrm{ha}$ and $18 \mathrm{~kg} / \mathrm{ha}$ representing densities of 50,400 and 800 seeds $/ \mathrm{m}^{2}$.

\section{2. Cuttings}

The alfalfa was harvested two times in the seeding year. Due to a slightly late seeding date, the first harvest was delayed until August 8, a period of 100 days, which is satisfactory for plant development. The second harvest was postponed until October 26, a relatively late cutting date, but a date that is possible under Michigan growing conditions. A period of 79 days elapsed between the two cuttings.

The plots were divided into 3 equal parts, and within each part a $0.21 \mathrm{~m}^{2}$ area of plants was removed by using a shovel. Both the tops and roots of the alfalfa and weeds were stored in plastic bags for further anlysis. By using sampling techniques equivalent to gradient analysis in ecological studies, the treatments were replicated six times and covered the entire weed population of the area.

\section{3. Laboratory studies}

In the laboratory studies each sample was separated into categories of a) alfalfa, b) weeds and c) inert material. Weeds were indentified and the tops and the roots were separated. Alfalfa and the different weeds were counted. After root washing, the tops and roots of the alfalfa and the weeds were allowed to dry for 3 days at $75^{\circ} \mathrm{C}$ after which the dry matter production was determined for each sample. In the second cutting, the root dry matter production which was determined for each sample. was sampled from the top 6 inches of the root.

\section{4. Calculating Methods}

2. 4. 1. Importance values, determinants of competition

In this study the main phytosociological characters of relative frequency, relative density and relative dominance of different species were determined. The synthetic importance value represents these three values together. The characters are the measurements used in gradient analysis in ecolocical measurements. The following formulas were used (CuRTIS and Mc Intosh 1950, WHITTAKER 1967):

\footnotetext{
a. Relative frequency of species $\mathrm{A}=\frac{\text { Frequency of species } A \times 100}{\text { Sum of frequency values for all species }}$

b. Relative density of species $\mathrm{A}=\frac{\text { No. of inviduals of species } A \times 100}{\text { Total no. of inviduals of all species }}$

c. Relative biomass dominance of species $\mathrm{A}=\frac{\text { Dominance of species } A \times 100}{\text { Total dominance of all species }}$

d. Important value $=$ Rel.freq. + rel. dens. + rel. dom.
} 
2. 4. 2. Yielding ability of population and invidual plant as influenced by plant competition

From the studies carried out by de WiT (1960) it can be concluded that if only the number of the plants $(Z)$ per unit area varies, the yield (Os) produced by the population can be estimated with the following equation (1):

(1) $\mathrm{O}_{\mathrm{s}}=\frac{\beta \Omega}{\beta+\mathrm{Z}^{-1}}$

where constants $\beta$ and $\Omega$ can be calculated. According to the equation, by raising the plant density one approaches the theoretical maximum yield level (Fig. $1 \mathrm{~A}$ ).

If both sides of the equation obtain inverse values the equation follows the formula:

(2) $\frac{1}{\mathrm{O}_{\mathrm{s}}}=\frac{\beta+\mathrm{Z}^{-1}}{\beta \Omega}$

$$
\mathrm{O}_{\mathrm{s}}^{-1}=\frac{\beta}{\beta \Omega}+\frac{1}{\beta \Omega} \cdot \mathrm{Z}^{-1}=\frac{1}{\Omega}+\frac{1}{\mathrm{~B} \Omega} \cdot \frac{1}{\mathrm{Z}}
$$

The inverse values of the yield per unit area and the population density of the same surface area determine the empirical constants of $\Omega$ and $\beta \Omega$.

The yield (a) of an invidual plant can be calculated by dividing both sides of the equation (1) with the number of plants $(Z)$ : Equation (2) can be drawn as follows:

(2) $\quad \alpha=\frac{\mathrm{O}_{\mathrm{s}}}{\mathrm{Z}}=\frac{\beta \Omega}{\frac{\beta+\mathrm{Z}^{-1}}{\mathrm{Z}}}=\frac{\beta \Omega}{\beta \mathrm{Z}+\mathrm{Z} \cdot \mathrm{Z}^{-1}}=\frac{\beta \Omega}{\beta \mathrm{z}+1}$

According to the equation, the yield of an invidual plant approaches the upper limit of the theoretical maximum yield as the number of plants decreases and the growing space of an invidual plant increases (Fig. $1 \mathrm{~B}$ ).

If both sides of the equation (2) obtain inverse values the equation follows the formula:

(3) $\frac{1}{\mathrm{a}}=\frac{\beta \mathrm{Z}+1}{\beta \Omega}=\frac{\beta \mathrm{Z}}{\beta \Omega}+\frac{1}{\beta \Omega}$

$\mathrm{a}^{-1}=(\beta \Omega)^{-1}+\Omega^{-1} \cdot \mathrm{Z}$

If the inverse values of the yield of the invidual plants and the corresponding densities are drawn between the co-ordinating axes, the relationship is linear and the empirical constants $\Omega$ and $\beta \Omega$ can be determined by linear regression. 
2. 4. 3. Relative crowding coefficients, determinants of competition

According to de WIT et al. (1960) the reproductive rate of alfalfa (a) in a mixture of alfalfa and weeds (w) is equal to

$\mathrm{a}_{\mathrm{aw}}=\left(\mathrm{O}_{\mathrm{a}} \mathrm{Z}_{\mathrm{a}}^{-1}\right)\left(\mathrm{O}_{\mathrm{w}} \mathrm{Z}_{\mathrm{w}}^{-1}\right)^{-1}=\mathrm{K}_{\mathrm{aw}} \mathrm{M}_{\mathrm{a}} \mathrm{Mw}^{-1}$

where

$\mathrm{O}_{\mathrm{a}}=$ yield of alfalfa

$\mathrm{O}_{\mathrm{w}}=$ yield of weeds

$\mathrm{Z}=$ number of plants per unit area

$\mathrm{M}_{\mathrm{a}}=$ monoculture yield or theoretical maximum yield of alfalta

$\mathrm{M}_{\mathrm{w}}=$ monoculture yield or theoretical maximum yield of weeds

$\mathrm{K}_{\mathrm{aw}}=$ the relative crowding coefficient of alfalfa with respect to weeds

The equation with respect to $\mathrm{K}_{\mathrm{aw}}$ can be solved as follows:

$\mathrm{K}_{\mathrm{aw}}=\left(\mathrm{O}_{\mathrm{a}} \mathrm{Z}_{\mathrm{a}}^{-1}\right)\left(\mathrm{O}_{\mathrm{w}} \mathrm{Z}_{\mathrm{w}}^{-1}\right)^{-1}\left(\mathrm{M}_{\mathrm{w}} \mathrm{M}_{\mathrm{a}}^{-1}\right)$

$\left.\mathrm{K}_{\mathrm{aw}}=\left(\mathrm{O}_{\mathrm{a}} \mathrm{O}_{\mathrm{w}}\right)^{-1}\right)\left(\mathrm{Z}_{\mathrm{w}} \mathrm{Z}_{\mathrm{a}}^{-1}\right) \quad\left(\mathrm{M}_{\mathrm{w}} \mathrm{M}_{\mathrm{a}}^{-1}\right)$

The relative crowding coefficient characterizes not the process of crowding itself but only the result of this crowding (de Wit 1960).

\section{Results and discussion}

\subsection{Cultivated plant community and plant competition described by importance values}

Gradient analysis is a research approach for studying the spatial pattern of vegetation. It seeks to understand the structure and variation of the vegetation of a certain surface area in terms of gradients in space of variables on three levels environmental factors, species populations and characteristics of communities. Gradient analysis and classification are alternative approaches to the vegetation of an area (WhitTAKER 1967). Gradient analysis of vegetation can be a direct gradient analysis with the procedures of a ransect along a single gradient, sometimes ordination measurements of hyperspaces and evolution. Gradient analysis can also contain similarity measurements with quantitative classification, factor analysis, early Wisconsin gradient analysis or Wisconsin comparative ordination analysis (WHITTAKER 1967). Each method necessitates a number of terms to be defined in advance. These terms are listed ans discussed by CuRTIS and Mc Intosh (1950) and WhitTaker (1967). The most important terms are frequency, density, abundance, constancy, presence and dominance consisting of species biomass or production as an expression of the amount of organic matter produced, or energy bound, per unit of ground surface per unit of time.

\section{R e sult s:}

Importance values of different crop species represent added values of relative frequency, relative density and relative dominance. In this particular study the importance values were used to show plant population changes with 
herbicide controlled and noncontrolled field conditions at several alfalfa seeding rates. Relative frequency, density, dominance and importance values in the first harvest are shown in Table 1 and from the second harvest in Table 2.

\section{A. First harvest}

Relative frequency values:

In uncontrolled field conditions at a low seed rate of alfalfa, witchgrass (Panicum capillare) and prostrate pigweed of the species group Amaranthus $s p p$ had the sama frequency, followed by red root pigweed (Amaranthus $s p p$ ) and purslane (Portulaca $s p p$ ) (Table 1). When the herbicide was applied, alfalfa, purslane and witchgrass had the highest frequencies and both pigweeds were usually eliminated by the herbicide treatment.

At $9 \mathrm{~kg} / \mathrm{ha}$ seeding density alfalfa had the same $\mathrm{RF}$-value as red root pigweed (Amaranthus $s p p$ ), purslane (Portulaca $s p p$ ) witchgrass (Panicum capillare) and prostrate pigweed (Amaranthus $s p p$ ) in the plots receiving no weed control (Table 1). The frequency of most weeds was lowered under field conditions with weed control. However, purslane and witchgrass retained the same RF-values as alfalfa.

At the alfalfa seeding rate of $18 \mathrm{~kg} / \mathrm{ha}, \mathrm{RF}$-values without weed control were the same for alfalfa, purslane and withchgrass. When the herbicide was applied the trend for the weed species, previously mentioned, was the same as for the $9 \mathrm{~kg}$ seeding rate. The RF-values of alfalfa and weeds were equal at all seeding rates in controlled and noncontrolled conditions (Fig. 2).
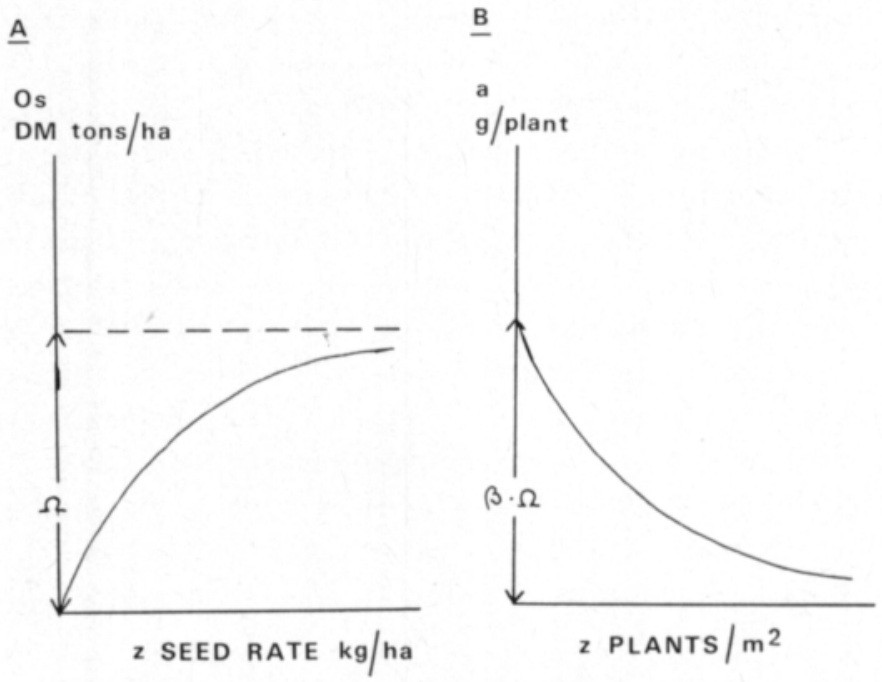

Fig. 1. Effect of seed rate $(\mathrm{kg} / \mathrm{ha})$ on the yield of population $\left(\mathrm{O}_{\mathrm{s}}\right.$ tons/ha), Fig. $1 \mathrm{~A}$ and the effect of the number of plants $\left(Z\right.$ plants $\left./ \mathrm{m}^{2}\right)$ on the yied of individual plant (g/plant), Fig. 1 B. 


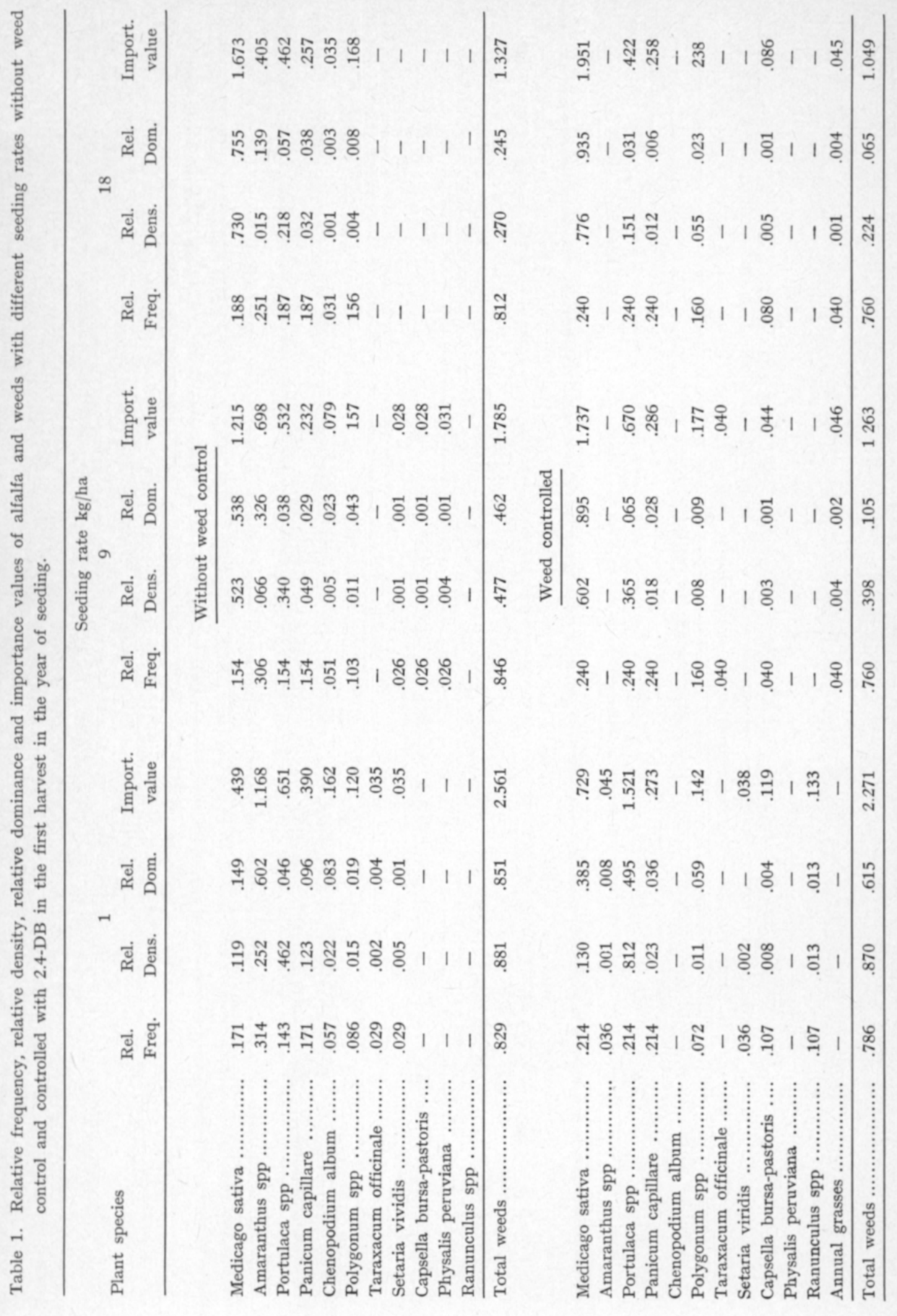




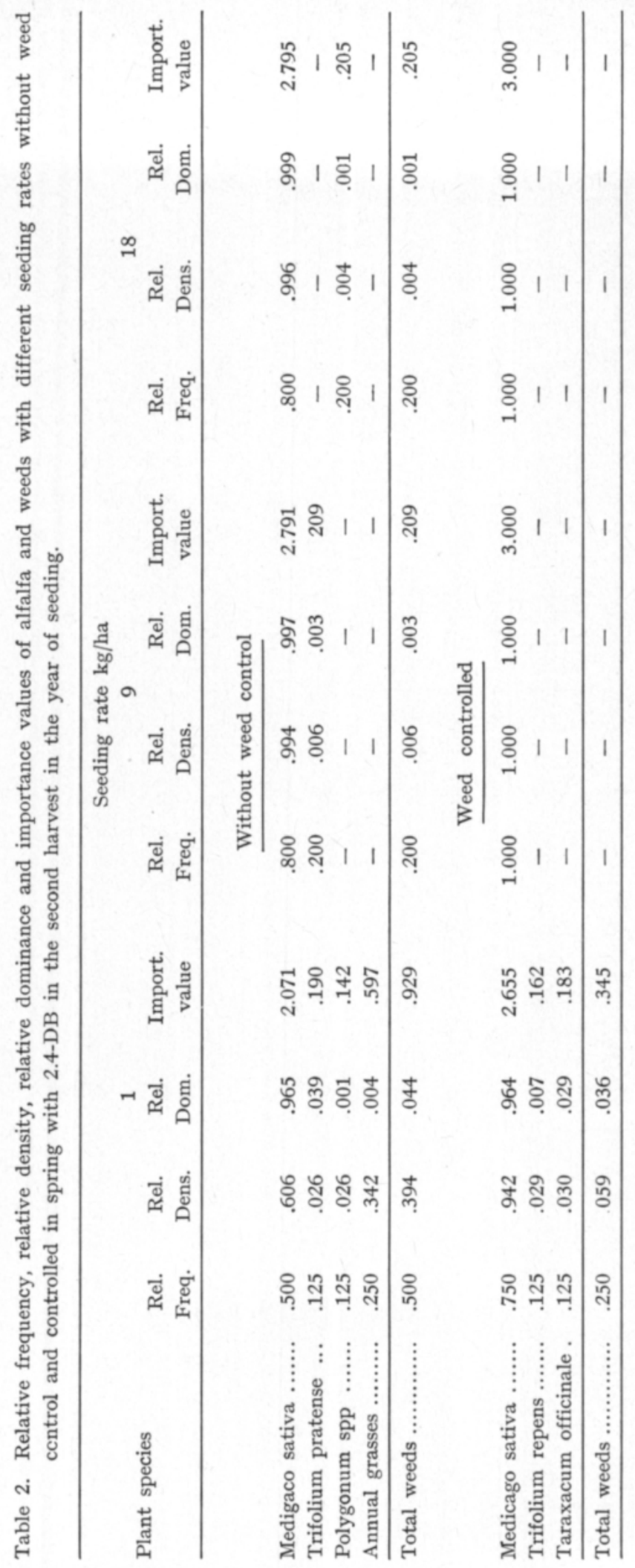



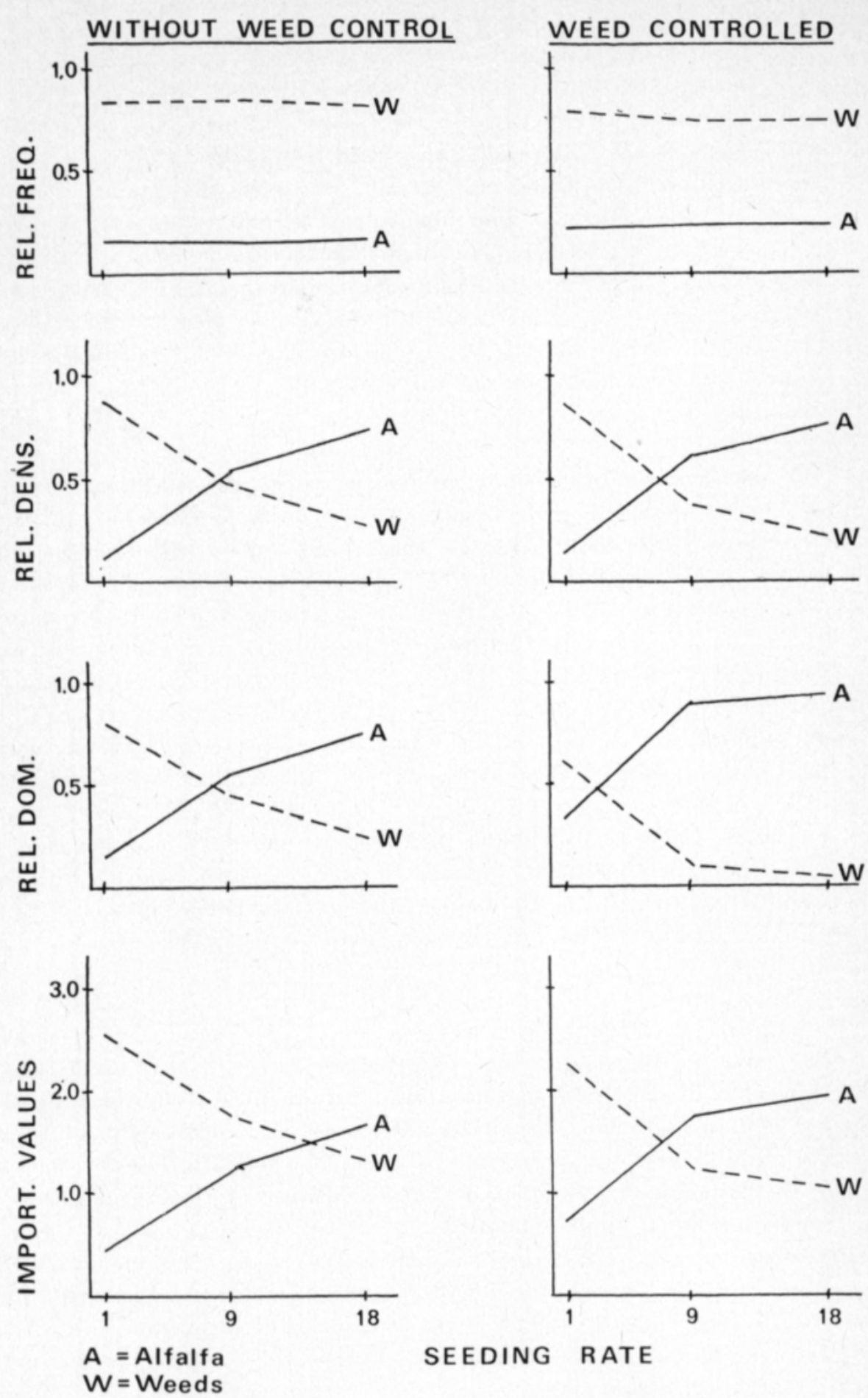

SEEDING RATE

Fig. 2. Relative frequency, relative density, relative dominance and relative importance values of alfalfa and weeds at different population densities in herbicide controlled and noncontrolled alfalfa stands. 
Relative density values:

At the lowest seeding rate and without weed control purslane had approximately three times the density value of alfalfa (Table 1). Red root pigweed and witchgrass ranked intermediate in their values. Under controlled conditions, purslane was the only important weed.

At the $9 \mathrm{~kg} / \mathrm{ha}$ alfalfa seeding rate purslane was again the commonest weed component for both controlled and noncontrolled conditions. The trend at the $18 \mathrm{~kg} /$ ha seeding rate was similar to that found for the $9 \mathrm{~kg} / \mathrm{ha}$ seeding rate. Only purslane (Portulaca $s p p$ ) had the same importance in both systems.

The relative density of alfalfa exceeded the relative density of all weeds at the alfalfa seeding rate of $9 \mathrm{~kg} / \mathrm{ha}$ in noncontrolled field conditions with a slightly lower rate in controlled conditions (Fig. 2).

\section{Relative dominance values:}

At the low seeding rate for alfalfa in noncontrolled field conditions red root pigweed (Amaranthus $s p p$ ) had a very strong relative dominance value. It was about three times that of alfalfa. When weed control was used, the pigweeds were mostly eradicated and purslane exceeded the level of alfalfa (Table 1).

At the seeding rate of $9 \mathrm{~kg} / \mathrm{ha}$ in noncontrolled field conditions red root pigweed was of major importance. However, its relative dominance value was lower than that of alfalfa. In the herbicide controlled system the dominance values of weeds were very low (Table 1).

At the high rate of seeding purslane was of importance in both the herbicide controlled and noncontrolled conditions as was pigweed in the noncontrolled conditions.

The relative dominance of alfalfa in respect of the relative dominance of weeds under noncontrolled field conditions showed the same trend as with the values of relative density (Fig. 1). In the case of the herbicide controlled stand the dominance of alfalfa exceeded the dominance of weeds at a very low rate of seeding.

Important values:

At the low rate of seeding, weeds competed very strongly with alfalfa when no herbicide was used. The Amaranthus species in Michigan conditions seemed to be the greatest problem for alfalfa. Purslane was another big problem. Other strong competitors were witchgrass and lambsquarter (Chenopodium album). In the herbicide treated stand purslane played an important role as a main competitor with alfalfa (Table 1).

At the seeding rate of $9 \mathrm{~kg} / \mathrm{ha}$ of alfalfa and when no herbicide was used, red root pigweed, purslane and witchgrass had a combined importance value similar to that of alfalfa. In the herbicide controlled stand purslane and witchgrass were the two most important weeds (Table 1).

The importance values (Fig. 2) show that in the noncontrolled field conditions the importance of alfalfa in respect of weeds increases linearly from the seeding rate of $1 \mathrm{~kg} / \mathrm{ha}$ up to the studied level of $18 \mathrm{~kg} / \mathrm{ha}$. At the same time the importance of weeds decreases, also linearly. In the case of the weed controlled stand, and with the seeding rate greater than $9 \mathrm{~kg} / \mathrm{ha}$, the changes 
in importance values of alfalfa and weeds are of minor importance. The values for alfalfa and weeds are equal at the seeding rates of $14 \mathrm{~kg} / \mathrm{ha}$ and $7 \mathrm{~kg} / \mathrm{ha}$ in the noncontrolled and controlled stands respectively.

\section{B. Second harvest}

Weeds did not play an important role in the second cutting. The first harvest eliminated most of the annual broad-leaved weeds although some red clovers, ladino clovers and annual grasses were found in the second cutting. The importance value of grasses seems to play a certain role in a $1 \mathrm{~kg} / \mathrm{ha}$ alfalfa stand, no importance was however, found in the other treatments (Table 2). Red clover seemed to invade the areas where some of the weed species had been eliminated, but this was of little consequence.

\section{2. Cultivated plant community and plant competition described by crowding coefficients}

Competition among plants can be either intraspecific or interspecific. Intraspecific plant competition takes place within a pure stand. In the mixed stand the competition is mainly interspecific but also intraspecific. The competitive ability of a species is not an absolute factor but is influenced by the composition of the stand and environment (BAEUMER 1964). Crowding coefficients describing competition among species have been introduced by several plant scientists.

A parameter which describes the development of the mixed stand adequately is the relative reproductive rate (RRR) introduced by de WIT and van den BERGH (1965). Another method widely used is the one introduced by LAMPETER (1960) and applied by Hofer (1970) and ERviö (1972). The calculation method used in this study is a modification of the method introduced by de WrT (1960).

Results:

At a low seeding rate of alfalfa the interspecific competition of alfalfa in respect to weeds takes place especially when there is no weed control. However, alfalfa competes well with weeds at low population densities of alfalfa (Table 3). The relative crowding coefficient of alfalfa at one $\mathrm{kg} / \mathrm{ha}$ seed rate in a stand without weed control was three times that found in the stand where weed control was used. The same trend can be seen among yields (Table 5). The increase in the yields of alfalfa was relatively low in respect to the decrease in the yields of weeds when no control vs. weed control was used.

When the seed rate of alfalfa was increased beyond the population densities of $9 \mathrm{~kg} / \mathrm{ha}$, weeds no longer played an important role and the crowding coefficients $\left(\mathrm{K}_{\mathrm{aw}}\right)$ evened out when both no control and weed control were used.

In the case of population density developing from the $9 \mathrm{~kg} / \mathrm{ha}$ seed rate or more, there was vigorous intraspecific competition of alfalfa and no changes in $\mathrm{K}_{\text {aw }}$ could be found (Table 3 ).

It is important to note that in the competition of weeds in respect to alfalfa $\left(\mathrm{K}_{\mathrm{wa}}\right)$ no changes could be found (Table 3$)$. The same trend was observed when no control was used or the stand was controlled by herbicides. 
Table 3. Relative crowding coefficient of alfalfa with respect to weeds $\left(\mathrm{K}_{\mathrm{aw}}\right)$ and weeds with respect to alfalfa $\left(\mathrm{K}_{\mathrm{wa}}\right)$ at different population densities without weed control and stand controlled with herbicides.

\begin{tabular}{|c|c|c|c|c|c|c|}
\hline & \multirow{2}{*}{$\begin{array}{c}\text { Seeding } \\
\text { rate } \\
\mathrm{kg} / \mathrm{ha}\end{array}$} & \multicolumn{2}{|c|}{$\begin{array}{l}\text { Relative crowding } \\
\text { coefficient }\end{array}$} & \multirow{2}{*}{$\begin{array}{l}\text { Seeding } \\
\text { rate } \\
\mathrm{kg} / \mathrm{ha}\end{array}$} & \multicolumn{2}{|c|}{$\begin{array}{l}\text { Relative crowding } \\
\text { coefficient }\end{array}$} \\
\hline & & $\mathrm{K}_{\mathrm{aw}}$ & $\mathrm{K}_{\mathrm{wa}}$ & & $\mathrm{K}_{\mathrm{aw}}$ & $\mathrm{K}_{\mathrm{wa}}$ \\
\hline & \multicolumn{3}{|c|}{ Without weed control } & \multicolumn{3}{|c|}{ Weed controlled } \\
\hline & 1 & 3.0 & .3 & 1 & 1.0 & .5 \\
\hline & 9 & 2.5 & .4 & 9 & 2.1 & .5 \\
\hline & 18 & 2.5 & .4 & 18 & 2.1 & .5 \\
\hline
\end{tabular}

Table 4. The calculated theoretical maximum yield of an invidual alfalfa plant top and root $(\beta \Omega)$, the calculated theoretical maximum top and root yields of alfalfa stand per unit area $(\Omega)$ in the first harvest in the year of seeding without weed control and controlled with herbicides.

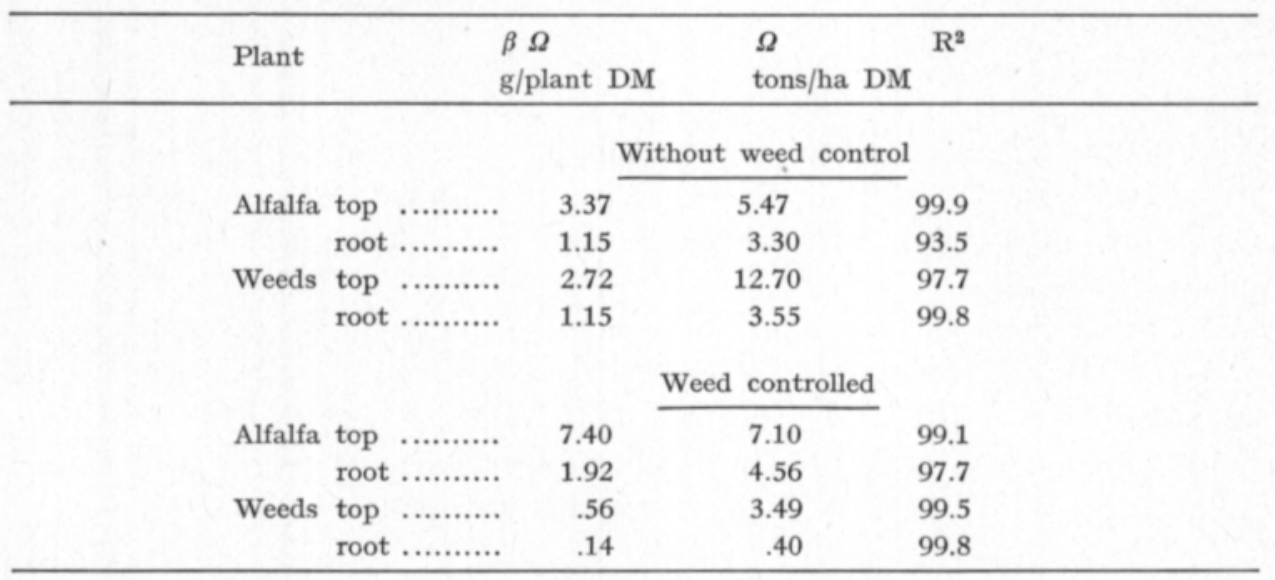

Table 6. Total biomass of alfalfa and weeds, root, top as a percent (\%) produced per unit area in two cuts in the year of seeding.

\begin{tabular}{|c|c|c|c|c|c|c|}
\hline $\begin{array}{c}\text { Seeding } \\
\text { Rate } \mathrm{kg} / \mathrm{ha}\end{array}$ & Roots & $\begin{array}{l}\text { Alfalfa } \\
\text { Top }\end{array}$ & $\begin{array}{c}\% \text { of total biomass } \\
\text { Total }\end{array}$ & Roots & $\begin{array}{c}\text { Weeds } \\
\text { Top }\end{array}$ & Total \\
\hline & & & Without weed control & & & \\
\hline 1 & 11.6 & 30.8 & 41.7 & 9.5 & 47.9 & 58.3 \\
\hline 9 & 21.0 & 56.0 & 77.0 & 1.9 & 20.3 & 23.0 \\
\hline 18 & 23.6 & 65.5 & 891 & 1.3 & 10.1 & 10.9 \\
\hline \multirow[t]{2}{*}{ Avg. } & 18.7 & 50.8 & 69.3 & 4.2 & 26.1 & 30.7 \\
\hline & & & Weed controlled & & & \\
\hline 1 & 18.1 & 49.4 & 67.6 & 3.0 & 28.2 & 32.4 \\
\hline 9 & 22.5 & 72.2 & 94.8 & 0.6 & 4.5 & 5.2 \\
\hline 18 & 23.0 & 73.7 & 96.7 & 0.6 & 2.5 & 3.3 \\
\hline Avg. & 212 & 651 & 86.4 & 1.4 & 11.7 & 13.6 \\
\hline
\end{tabular}


Table 5. Seeding year top, root and total yields tons/ha of alfalfa and weeds, controlled and without weed control seeded at tree densities and cut two times.

\begin{tabular}{|c|c|c|c|c|c|c|c|c|c|c|c|}
\hline & \multirow{2}{*}{\multicolumn{2}{|c|}{$\begin{array}{l}\text { Alfalfa seeding } \\
\text { rate } \mathrm{kg} / \mathrm{ha}\end{array}$}} & \multirow{3}{*}{ Top } & \multirow{2}{*}{$\begin{array}{l}\text { Cut } 1 \\
\text { Root } \\
\end{array}$} & \multirow[b]{2}{*}{ Total } & \multirow{2}{*}{\multicolumn{2}{|c|}{$\begin{array}{l}\text { Cut } 2 \\
\text { Root }\end{array}$}} & \multirow[b]{2}{*}{ Total } & \multicolumn{3}{|c|}{ Cuts total } \\
\hline & & & & & & & & & Top & Root & Total \\
\hline & & & & & & Withou & weed & control & & & \\
\hline \multirow[t]{12}{*}{ ALFALFA } & 1 & & $1.21 \mathrm{a}$ & $.41 \mathrm{a}$ & $1.62 \mathrm{a}$ & $3.23 \mathrm{a}$ & $1.67 \mathrm{a}$ & $4.90 \mathrm{a}$ & $4.44 \mathrm{a}$ & $1.67 \mathrm{a}$ & $6.11 \mathrm{a}$ \\
\hline & 9 & & $3.71 \mathrm{~b}$ & $1.54 \mathrm{ab}$ & $5.25 b$ & $5.13 \mathrm{~b}$ & $3.27 \mathrm{~b}$ & $8.40 \mathrm{~b}$ & $8.84 b$ & $3.27 \mathrm{~b}$ & $12.11 \mathrm{~b}$ \\
\hline & 18 & & $4.49 \mathrm{~b}$ & $2.57 \mathrm{~b}$ & $7.06 \mathrm{~b}$ & $5.19 b$ & $3.52 \mathrm{~b}$ & $8.71 \mathrm{~b}$ & $9.68 \mathrm{~b}$ & $3.52 \mathrm{~b}$ & $13.20 \mathrm{~b}$ \\
\hline & & Avg. & 3.14 & 1.51 & 4.64 & 4.52 & 2.82 & 7.34 & 7.65 & 2.82 & 10.47 \\
\hline & & & & & & We & ed cont & rolled & & & \\
\hline & 1 & & $1.70 \mathrm{a}$ & $.55 \mathrm{a}$ & $2.25 \mathrm{a}$ & $3.21 \mathrm{a}$ & $1.79 \mathrm{a}$ & $5.00 \mathrm{a}$ & $4.91 \mathrm{a}$ & $1.79 \mathrm{a}$ & $6.70 \mathrm{a}$ \\
\hline & 9 & & $5.60 \mathrm{~b}$ & $2.71 \mathrm{~b}$ & $8.31 b$ & $5.64 \mathrm{~b}$ & $3.50 \mathrm{~b}$ & $9.14 \mathrm{~b}$ & $11.24 \mathrm{~b}$ & $3.50 \mathrm{~b}$ & $14.74 \mathrm{~b}$ \\
\hline & 18 & & $5.60 \mathrm{~b}$ & $2.92 b$ & $8.52 b$ & $5.89 \mathrm{~b}$ & $3.62 \mathrm{~b}$ & $9.51 \mathrm{~b}$ & $11.49 \mathrm{~b}$ & $3.62 \mathrm{~b}$ & $15.11 \mathrm{~b}$ \\
\hline & & Avg. & 4.30 & 2.06 & 6.36 & 4.91 & 2.97 & 7.88 & 9.21 & 2.97 & 12.18 \\
\hline & $\mathrm{LSD}_{\cdot 00}$ & Tmts & NS & NS & NS & NS & NS & NS & NS & NS & NS \\
\hline & & Rates & 2.14 & 1.68 & 3.77 & .25 & .26 & 1.17 & 3.00 & .26 & 3.14 \\
\hline & & & & & & Without & weed & control & & & \\
\hline \multirow[t]{9}{*}{ WEEDS } & 1 & & 6.97 & 1.39 & 8.36 & 12 & .05 & .17 & 7.09 & 1.44 & 8.53 \\
\hline & 9 & & 319 & .35 & 3.54 & .01 & .01 & .02 & 3.20 & .36 & 3.56 \\
\hline & 18 & & 1.46 & .17 & 1.63 & - & - & - & 1.46 & 17 & 1.63 \\
\hline & & Avg. & 3.87 & .64 & 4.51 & .04 & .02 & .06 & 3.92 & .67 & 4.57 \\
\hline & & & & & & We & ed cont & trolled & & & \\
\hline & 1 & & 2.71 & .33 & 3.04 & .12 & .04 & .16 & 2.83 & .37 & 3.20 \\
\hline & 9 & & .89 & .11 & .77 & - & - & - & .66 & .11 & .77 \\
\hline & 18 & & .39 & .07 & .46 & - & - & - & .39 & .07 & .46 \\
\hline & & Avg. & 1.33 & .17 & 1.42 & .03 & .01 & .05 & 1.29 & 18 & 1.48 \\
\hline
\end{tabular}

\section{3. Discussion}

Among pure stands only intraspecific competition exists. In mixed stands, or in the stands where weed control has not been successful, both interspecific and intraspecific competition can be found. The growing potential of an individual plant is determined by the relative dominance of a plant or the population density of a species (BAEUMER, 1964).

In this particular study, both the applied ecological approach and the mathematical model suitable for quantitative measurements were used in evaluating the spring growth of alfalfa and weeds.

When studying the importance values of the stand it was found that the same weeds which were not affected by the herbicide treatment were not controlled by the biological weed control at the high alfalfa seeding rates. Importance values show that a crop competes best with weeds at high population densities as shown by Mann and Barnes (1945, 1947, 1949, 1950), Granström (1962), Horowitz (1966), ERviö (1972). Importance values also describe adequately the requirements of seeding rates for maximum yield in herbicide controlled 
and noncontrolled systems as observed in this study and in alfalfa studies by Pulli (1973).

The crowding coefficients primarily show the competitive ability of alfalfa and weeds, not the dominance situation or importance of the species at the moment. As a result of competition within the stand the equilibrium stage was reached at the population density of $9 \mathrm{~kg} / \mathrm{ha}$ (Table 3 ).

The equilibrium stage is reached by means of regulating both the vegetative growth of the stand and the number of inviduals as shown by HARPER (1960) and HARPER and GAIJIC (1961). It is interesting to note that the weeds generally have a very stable competitive ability at any alfalfa density in controlled or noncontrolled systems. This study clearly showed that weeds are very adaptable to various growing conditions due to the versatility between species. The excellent competitive ability of alfalfa could be seen at low seeding rates when no herbicide was used (Table 3). The damaging effect of herbicides can be seen especially at low seeding rates of alfalfa.

\section{4. Yield formation of alfalfa and weeds as influenced by intraspecific and interspecific plant competition}

3. 4. 1. Root and top weights of an individual alfalfa and weed plant

The calculated theoretical maximum seeding year spring yields of an invidual alfalfa and weed top and root are presented in Table 4 . The results show that the aboveground yield of alfalfa in a weed controlled system is more than two times greater than that in a noncontrolled system. The competition is more equal among shoots than among roots. With herbicide treatment the weeds are about five times smaller in controlled than in noncontrolled systems. The change in plant size is more stable and more gradual without weed control than in a controlled system when the population density of alfalfa is increased (Fig. 3). The decrease in the number of weeds in a controlled system in not drastic compared to the noncontrolled system, but the size of the weed plant is smaller.
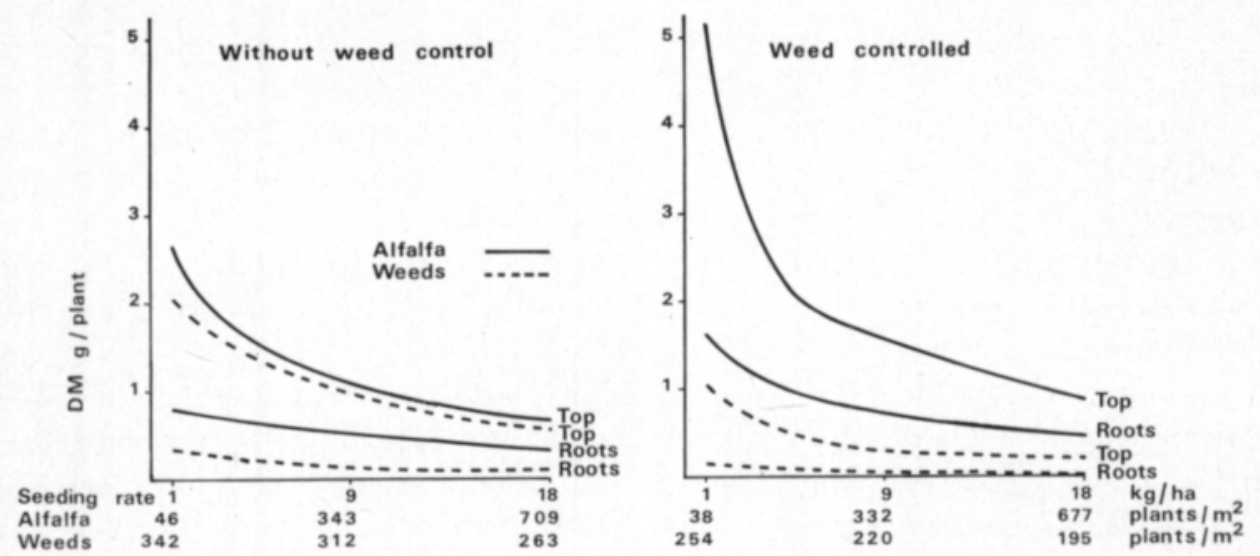

Fig. 3. Effect of the number of plants or the seeding rate of alfalfa on the dry matter weight of the alfalfa and weed shoot and root production $\mathrm{g} /$ plant in controlled and noncontrolled growing conditions. 
3. 4. 2. Yields of alfalfa and weeds

Theoretical maximum yields:

The calculated theoretical maximum yields of a unit area of alfalfa and weeds were obtained according to the way described by the WiT (1960). The results are shown in Table 4. Without weed control the calculated theoretical maximum yield of weeds in the noncontrolled system was more than twice that of alfalfa. In the controlled system the relationships were reversed. It is obvious that the competition took place mostly between the underground parts of plants as indicated by the root yields of 3.3 tons/ha of alfalfa and 3.6 tons/ha of weeds in the noncontrolled system. In the controlled system there was no room for weed roots as represented by the root yields of 4.6 tons/ha for alfalfa and 0.4 tons/ha for weeds.

Yields in cuts:

The maximum yield levels of shoots and roots in each cut and in total yields were obtained at the seeding rate of $9 \mathrm{~kg} / \mathrm{ha}$ (Table 5). Due to the experimental design, where herbicide treatments were in the main plot with only two replications, a statistical difference between treatments could not be found, although the differences were in favour of the controlled system. The negative correlation between the alfalfa and weed yields can be observed when the population density of alfalfa is increased. The weeds played an important role in the first cut at all seeding densities in the noncontrolled system and only at the lowest seed rate in the controlled system. In the second cut the weed problem was quite unimportant. The calculated yield curves of the stand spring growth obtained by the means of de WIT (1960) show the critical growth curves of alfalfa and weeds at different population densitied (Fig. 4).
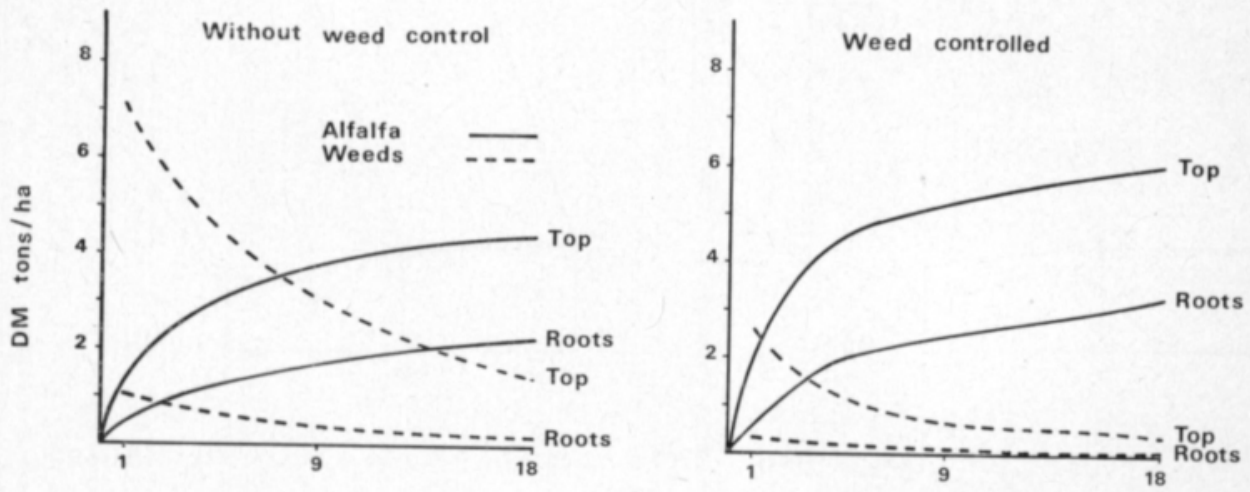

SEEDING RATE $\mathrm{kg} / \mathrm{ha}$

Fig. 4. Effect of the seeding rate of alfalfa on the shoot and root production of alfalfa and weeds (DM tons/ha) in weed controlled and noncontrolled growing conditions. 
Total biomass:

The total biomass yields of alfalfa and weeds in two cuts are presented in Fig. 5. The most important observation here is that the combined root, top and total biomass yields of alfalfa and weeds are equal at any seeding rate of alfalfa when no herbicide has been used in the management technique. The same yield levels were obtained also in the weed controlled system with the seeding rate of $9 \mathrm{~kg}$ or more of alfalfa seed per hectare. At the $1 \mathrm{~kg} / \mathrm{ha}$ seeding rate in the noncontrolled system the total biomass of weeds was $\mathbf{5 8 . 3} \%$ of the total biomass per unit area (Table 6). At the same population density in the controlled system the corresponding value was $32.4 \%$, indicating that there were too few plants per unit area to obtain the maximum biomass yields.

The relative proportions of alfalfa and weed root and top yields from the total biomass per unit area are presented in Table 6. Alfalfa roots have a high competitive ability compared to weeds and the root yield was very stable in both controlled and noncontrolled systems beyond the seeding rate of $9 \mathrm{~kg} / \mathrm{ha}$. Most of the changes occurred in aboveground competition giving a clear indication of the intraspecific and interspecific competition in the noncontrolled system and the predominantly intraspecific competition in the weed controlled system.

Without weed control

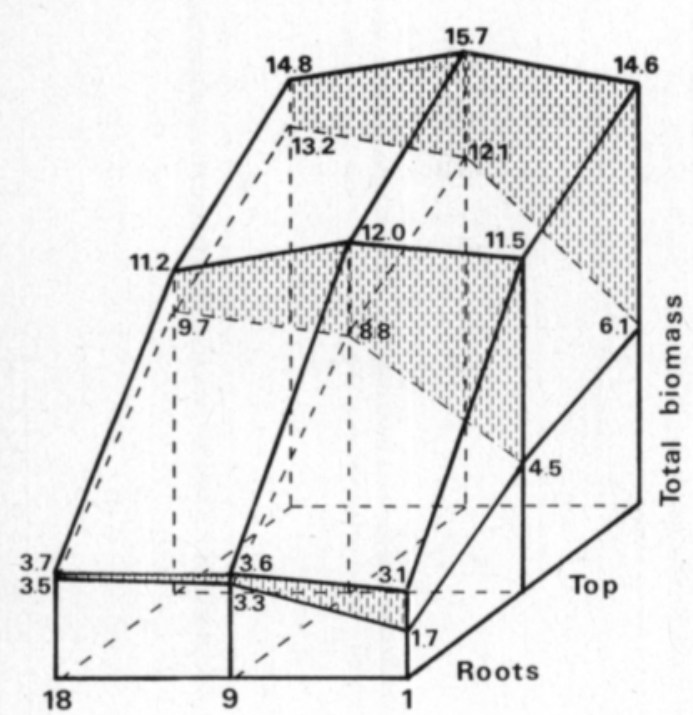

Weed controlled

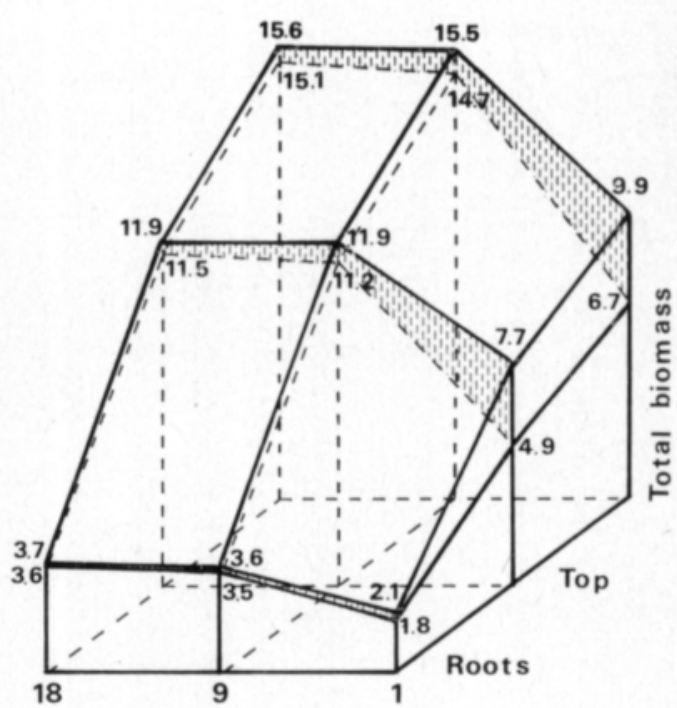

Alfalfa

Weeds

Fig. 5. Root; shoot and total biomass production of alfalfa and weeds at different seeding rates of alfalfa in weed controlled and noncontrolled growing conditions. 


\section{4. 3. Discussion}

Plants under natural conditions grow as heterogenic societies and in cultivated areas as limited mixed populations or as monocultures. However, also a monoculture is affected by the number of weeds even in controlled conditions. Competition between plants either in a monoculture or in a mixed stand develops if any one of the growth factors is limited. BAEUMER (1964) has stated that the greater the seeding rate the earlier the plants fill their space requirements. During the period without space limitation the plants grow at the same rate at all seeding densities. When the space requirements have been met, competition between the plants slows down the growth.

The decrease in growth is greater the denser the populationis. In dense populations the competition for light is one of the most dominant factors causing morphological changes among plants (STERN 1965). BAEUMER's and STERN's observations can be found also in this study. In noncontrolled growing conditions (Fig. 3) the changes in plant size are gradual and less radical due to the heavy competition between alfalfa and weeds already at the $1 \mathrm{~kg} / \mathrm{ha}$ seeding rate of alfalfa. In controlled growing conditions space requirements are met mainly around the seeding rate of $5 \mathrm{~kg} / \mathrm{ha}$ (Fig. 3).

The calculated theoretical maximum aboveground yields of alfalfa (Table 4) and the yield curves of alfalfa and weeds (Fig. 4), obtained according to the way introduced by de WIT (1960), show that the theoretical maximum yield of alfalfa in controlled growing conditions in the first cut of the seeding year was about $22 \%$ less than in noncontrolled growing conditions. The development of the alfalfa DM yield was less steep in the case of noncontrolled growing conditions compared to the curves for the controlled system (Fig. 4). The optimum seeding rate of alfalfa, $9 \mathrm{~kg} / \mathrm{ha}$, was equal to that obtained by PUlli (1973). In less favourable growing conditions and with the use of biological weed control the seeding rates of $16-33 \mathrm{~kg} / \mathrm{ha}$ (TESAR \& JACKoBS 1972 ) and $20-30 \mathrm{~kg} / \mathrm{ha}$, as recommended by Oswald (1959), Kemenesy and Manninger (1968) and Multamäki (1965), are needed for favourable growth and development in the year of seeding when no companion crop is used.

As regards biomass production, comparing weed controlled and noncontrolled systems, the results agree with the summary of ODUm (1971), that it may be stated that nature maximizes for gross production whereas man maximizes for net production. In a monoculture a certain population density is required in order to obtain the maximum yield. Beyond that environment dependent population density the only losses are from higher seeding expences.

\section{Summary and conclusions}

The study dealing with the intraspecific competition among alfalfa stands with different population densities and with the interspecific competition between alfalfa and weeds was conducted on the Michigan State University farm in East Lansing in 1972. An ecological approach to studying plant competition was made by testing an applied form of gradient analysis widely used in ecological mapping. The research involved a complementary study to 
the seeding year alfalfa development studies (PuLli 1973). The following results can be presented:

1. Importance values consisting of relative frequency, relative density and relative biomass dominance values calculated from six quadrats in each treatment described well the relative importance of alfalfa and weeds in the mixture.

2. Relative crowding coefficients could be calculated in the absence of a pure stand by using the calculated theoretical maximum yields based on the formulae introduced by de WiT (1960).

3. Importance values primarily indicated the quantity relationship of different species in mixed stands. Relative crowding coefficients principally characterized the competitive ability of a species in a mixed stand.

4. The importance of alfalfa exceeded the importance of weeds at the alfalfa seeding rate of $14 \mathrm{~kg} / \mathrm{ha}$ in noncontrolled field conditions. In the herbicide controlled stand the corresponding alfalfa seeding rate requirement was about $7 \mathrm{~kg} / \mathrm{ha}$.

5. Relative crowding coefficients showed that alfalfa has a very good competitive ability against weeds. In the case of mainly intraspecificc ompetition of alfafa there was no change in the crowding coefficient of alfalfa in respect to weeds.

6. The crowding coefficient of weeds in respect to alfalfa showed no changes in the noncontrolled or herbicide controlled growing conditions at any seeding rate indicating the variability and the plasticity of the weed species to adaptation to the available growing conditions and the good competition ability of alfalfa.

7. The defined growth curve was asymptotic in respect of population density. The maximum yield level in the first and second cut and in the total yield was obtained at the seed rate of $9 \mathrm{~kg} / \mathrm{ha}$. In noncontrolled field conditions the shape of the growth curve was less steep.

8. The total biomass production per unit area was equal in the noncontrolled system at all seeding rates and in the herbicide controlled system at the seeding rates of $9 \mathrm{~kg} / \mathrm{ha}$ or more indicating that nature maximizes the gross production and man the net production.

\section{REFERENCES}

Baeumer, K. 1964. Konkurrenz in Pflanzenständen als problem der Pflanzenbauforschung. Forschung und Beratung. B. 10: 99-103.

Соoк, S. A. 1965. Population regulation of Escholzia californica by competition and edaphic conditions. J. Ecol. 53: 759-769.

Curtis, J. T. \& R. P. Mc Intosh. 1950. The interrelations of certain analytic and synthetic phytosociological characters. Ecology 31: 434-455.

Erviö, L-R. 1972. Growth of weeds in cereal populations. J. Scient. Agric. Soc. Finl. 44: $19-28$.

Granström, B. 1959. Konkurrensen mellan ogräs och kulturväxten. Växtodling 10:11-12.

Harper, J. L. 1960. Factors controlling plant number. The biology of weeds p. 119-132. Oxford.

- \& GaIJIC, D. 1961. Experimental studies of the mortality and plasticity of a weed. Weed Res. 1: $91-104$. 
Hofer, H. 1970. Ủber die Zusammenhänge zwischen der Düngung und der Konkurrenzfähigkeit ausgewählter. Naturwiesenpflanzen. Diss. 4500:1-70. Zürich.

Holliday, R. 1960. Plant population and crop yield. Field Crop Abstr. 13: 159-167, $427-254$

Horowitz, M. 1966. Comparative development and competition of weed and cultivated plant: Phalaris paradoxa and wheat. Israel J. Bot. 15: 77.

Kemenesy, E. \& Manninger, C. A. 1968. Die Luzerne Anbau und Pflantzenschuts. 240 p. Budapest.

Lampeter, W. 1960. Gegenseitige Beeinflussung höherer Pflanzen in bezug auf Spross und Wurzel wachstum, Mineralstoffgehalt und Wasserverbrauch-untersucht an einigen wirtchaftlich wichtigen Futterpflanzen. Wis. Z. Univ. Leipzing. 9: 611-722.

MANN, H. H. \& BARNes, T. W. 1945, 1947, 1949, 1950. The competition between barley and certain weeds under controlled conditions I-IV. Ann. Appl. Biol. 32: 15, 34: 252, 36: 273, 37: 139-148.

Mc Intosh, Robert P. 1965. Community, competition and adaptation. Quart. Rev. Biol. 45: $259-280$.

MUนtaмāKI, K. 1965. Sinimailasen viljelystä. Koetoiminta ja Käyt. 22. 1-2: 1 .

Opum, E. R. 1971. Fundamentals of ecology. 574 p. W. B. Saunders Co, London

Oswald, H. 1959. Åkerns nyttoväxter. 590 p. Stockholm.

PoHJonen, V. 1974. Istutustiheyden vaikutus eräiden lyhytkiertoviljelyn puulajien ensimmäi. sen vuoden satoon ja pituuskasvuun. Silva Fennica 8: 115-127.

Pulli, S. 1973. Yields, root development, carbohydrate reserves and in vitro dry matter disappearance of spring seeded alfalfa ( $\mathrm{Medicago}$ sativa L.) treated with herbicides and harvested in the year of seeding.

Thesis for the degree of $\mathrm{Ph}$. D, Michigan State Unversity 1973. 88 p.

SAGAR, G. R. \& HARPER, J. L. 1960. Factors affecting the germination and early establishment of plantains (Plantago lanceolata, P. media and P. major). In J. L. Harper (ed.) The Biology of Weeds p. 236-246. Oxford Univ. Press. London.

STERN, W. 1965. The effect of density on the performance of individual plants in Subterranean clover swards. Aust. J. Agric. Res. 16: 541-553.

Tesar, M. B. \& Jackobs, J. A. 1972. Establishing the stand. In C. H. Hansen (ed,), Alfalfa Science and Technology, ASA monograph. N:o 15. Amer. Soc. Agr. Madison, Wisconsin pp 391-435.

WARING, R. H. \& MAJOR, J. 1964. Some vegetation of the California Coastal redwood region in relation to gradients of moisture, nutrients, light and temperature. Ecol. Monogr. $34: 167-215$.

Whittaker, R. H. 1967. Gradient analysis of vegetation. Biol. Rev. 49: 207-264.

De WrT, C. T. 1960. On competition. Versl. Landbouwk. Onderz, 66: 1-82.

- \& van den Bergh, J. 1965. Competition between herbage plants. Neth. J. Agric. Sci. 2: 212-221.

Ms received March 24, 1980. 


\title{
Lajin sisäisen kilpailun ja lajien välisen kilpailun vaikutus kylvövuoden sinimailasen kasvuun
}

\author{
SEPPO Pulci \\ Helsingin yliopisto, Kasvinviljelytieteen laitos, $00710 \mathrm{Helsinki} 71$.
}

Michigan State yliopiston koetilalla East Lansingissä Yhdysvalloissa perustettiin keväällä 1972 koe, jossa oli tarkoitus selvittää kylvövuoden sinimailasen kehitystä lajin sisäisen ja lajien välisen kilpailun vallitessa. Tätä varten koe perustettiin viljavalle, mutta erittäin runsaasti rikkakasveja sisältävälle kasvualustalle. Puolet ruuduista käsiteltiin herbisideillä Dalapon ja 2.4-DB. Tutkimuksen tarkoituksena oli selvittää käsittelemättömillä ruuduilla kasvilajien välistä kilpailua ja kăsitellyillä ruuduilla lajien sisäistä kilpailua. Lajin sisäistä kilpailua varten sinimailasen kylvōtiheydeksi valittiin 50, 400 ja 800 siementä/m².

Kilpailututkimuksiin sovellettiin kasviekologisissa tutkimuksissa suosittua gradienttianalyysiä, jolla pyrittiin määrittämään monipuolisesti kasvien väliset suhteet. Näitä kilpailusuhteita selvittäviä suureita olivat suhteellinen frekvenssi, suhteellinen tiheys, suhteellinen dominanssi ja näitä suureita yhdistävä tärkeyskerroin (importance value). Toisena kasvien välistä kilpailua kuvaavana suureena käytettiin de Wrr'in kehittämää suhteellista valtauskerrointa (crowding coefficient), jonka laskemiseksi määritettiin puhdaskasvustojen teoreettiset maksimisadot sekä sinimailaselle että rikkakasveille. Puhdaskasvustojen teoreettiset maksimisadot sekä yksityisen kasvin teoreettiset maksimisadot laskettiin de W1r'in kehittämän mallin mukaisesti.

Tutkimuksessa todettiin, että aikaisemmin maataloustutkimuksissa käyttämätöntä gradienttianalyysiä voitiin soveltaa viljelykasvien kilpailututkimuksiin. Samoin viljojen seoskasvustojen hyvin kuvaavaa suhteellista valtauskerrointa voitiin hyvin soveltaa nurmikasvien ja rikkakasvien välisen kilpailun ilmentäjäksi ilman, että käytettävissä oli puhtaitten rikkakasvustojen sato.

Eri tavoin määritetyistä kilpailua ilmentävistä kertoimista tärkeyskerroin (importance value) kuvasi ensisijaisesti eri kasvilajien paljoussuhteita seoskasvustossa kun taas suhteellinen valtauskerroin (relative crowding coefficient) ilmensi itse kilpailukykyä yhden lajin suhteessa toiseen kasvilajiin.

Sinimailasen ja rikkaruohojen välisen vapaan kilpailun vallitessa tarvittiin sinimailasen kylvömäärä $14 \mathrm{~kg} / \mathrm{ha}$ ennen kuin sinimailasen tärkeyskerroin ylitti rikkaruohojen tärkeyskertoimen. Herbisideillä käsitellyissä kasvustoissa vastaava tasapainotila saavutettiin siemenmäärällä $7 \mathrm{~kg} / \mathrm{ha}$.

Suhteelliset valtauskertoimet osoittivat, että sinimailanen on hyvä kilpailija, ja juuristo on sen vahvin kilpailutekijä. Kun sinimailasen kasvutiheys kasvaa tiettyyn pisteeseen, jossa kilpailu on pääasiassa lajin sisäistä kilpailua, sinimailasen valtauskerroin ei muutu suhteessa rikkaruohoihin, vaikka sinimailasen tiheys kasvaakin. Rikkakasvien valtauskerroin suhtessa sinimailaseen oli muuttumaton kaikilla sinimailasen kylvötiheyksillä sekä käsitellyissä että käsittelemättömissä kasvustoissa ilmentäen ominaisuuksiltaan monipuolista rikkakasvustoa ja hyvää sopeutumiskykyä.

Sinimailasen tiheydestä riippuvainen kasvumalli sopi asymptoottiseen kasvukäyrään ja tuotti maksimisadon ensimmäisessä ja toisessa niitossa sekä kokonaissadoissa siemenmäärällä $9 \mathrm{~kg} / \mathrm{ha}$. Rikkaruohoisissa kasvustoissa käyrän muoto oli kuitenkin herbisideillä käsitellyn kasvuston käyrää loivempi.

Pinta-alayksiköiltä tuotetun biomassan määrä (maanpäällinen ja maanalainen) oli herbisideillä käsittelemättömillä koejäsenillä sama kaikilla kylvötiheyksillä ja yhteneväinen kahden kcrkeimman kylvōtiheyden kanssa herbisideillä käsitellyillä koejäsenillä. Tutkimus ilmentää sen tosiasian, että luonto maksimoi bruttotuotannon, ihminen nettotuotannon. 